\title{
Cross-Contamination of Lettuce (Lactuca sativa L.) with Escherichia coli 0157:H7 via Contaminated Ground Beef ${ }^{\dagger}$
}

\author{
MARIAN R. WACHTEL, ${ }^{1}+$ JAMES L. MCEVOY,${ }^{1 *}$ YAGUANG LUO, ${ }^{1}$ ANISHA M. WILLIAMS-CAMPBELL, ${ }^{2}$ AND \\ MORSE B. SOLOMON ${ }^{2}$
}

\begin{abstract}
${ }^{1}$ U.S. Department of Agriculture, Agricultural Research Service, Beltsville Agricultural Research Center-West, Plant Sciences Institute, Produce Quality and Safety Laboratory, Building 002, Room 117, 10300 Baltimore Avenue, Beltsville, Maryland 20705; and ${ }^{2}$ U.S. Department of Agriculture, Agricultural Research Service, Food Technology and Safety Laboratory, Building 201, 10300 Baltimore Avenue, Beltsville, Maryland 20705, USA
\end{abstract}

MS 02-261: Received 2 August 2002/Accepted 4 December 2002

\begin{abstract}
A lettuce outbreak strain of $E$. coli $\mathrm{O} 157: \mathrm{H} 7$ was used to quantitate the pathogen's survival in ground beef and its transfer to hands, cutting board surfaces, and lettuce. Overnight storage of inoculated beef at $4^{\circ} \mathrm{C}$ resulted in no pathogen growth, while room-temperature storage allowed multiplication. Hamburger patty formation allowed the transfer of bacteria to hands. Contaminated fingers subsequently transferred the pathogen to lettuce during handling. E. coli was transferred from hamburgers to cutting board surfaces; overnight storage of boards decreased the numbers of recoverable pathogens by $\sim 1 \log$ CFU. A 15-s water rinse failed to remove significant numbers of pathogens from cutting boards whether it was applied immediately after contamination or following overnight room-temperature storage. Three lettuce leaves were successively applied to a single contaminated cutting board area both immediately after contamination and after overnight room-temperature storage of contaminated boards. Another set of leaves was pressed onto boards immediately following contamination and was then stored overnight at $4^{\circ} \mathrm{C}$ before pathogen enumeration. The numbers of pathogens transferred to the first pressed leaves were larger than those transferred to the second or third leaves. There were no significant differences in the numbers of pathogens recovered from leaves pressed immediately after contamination whether pathogens were enumerated immediately or following overnight storage at $4^{\circ} \mathrm{C}$. However, fewer pathogens were transferred to leaves pressed to boards stored overnight at room temperature prior to contact with lettuce. Twenty-five lettuce pieces were successively pressed onto one area on a board containing 1.25 $\times 10^{2} \mathrm{CFU}$ of $E$. coli. Pathogens were transferred to $46 \%$ of the leaves, including the 25 th exposed leaf.
\end{abstract}

Postharvest contamination and growth of bacterial pathogens on produce can occur via several mechanisms, including contamination of transport equipment, processing wash water, or ice; temperature abuse during storage or packaging; and cross-contamination from other foods (5). In recent years, several Escherichia coli O157:H7 outbreaks have been caused by the consumption of lettuce or salad contaminated after harvest. Although farm-to-fork food safety practices have received much attention recently, outbreaks caused by poor adherence to these standards continue to occur.

Thirty Boy Scouts were infected with E. coli O157:H7 in 1995 after consuming lettuce that had been stored with raw beef (12). A restaurant salad bar was the source of a 1999 E. coli O157:H7 outbreak that sickened 46 people. The pathogen was thought to have been transferred to salad via preparation by an infected food handler (11). In March 1999, 72 people fell ill during an E. coli O157:H7 outbreak in Kearney, Nebr. Case patients were infected with the path-

\footnotetext{
* Author for correspondence. Tel: 301-504-6983; Fax: 301-504-5107; Email: mcevoyj@ba.ars.usda.gov.

$\dagger$ Mention of a trademark or proprietary product does not constitute a guarantee or warranty of the product by the USDA and does not imply its approval to the exclusion of other products that may also be suitable

\$ Present address: Infectious Diseases and Microbiology IRG, Center for Scientific Review, National Institutes of Health, Room 4182, 6701 Rockledge Drive, Bethesda, MD 20892, USA.
}

ogen via contaminated iceberg lettuce at a restaurant salad bar. Epidemiologic analysis implicated a sick restaurant employee and improper storage procedures in the outbreak (16).

Previously, we simulated the lettuce contamination and storage conditions found in the Nebraska restaurant to determine the extent of possible pathogen cross-contamination and growth during chopping, washing, and storage (18). We noted the lack of information in the literature on the potential for the growth of E. coli $\mathrm{O} 157: \mathrm{H} 7$ in ground beef as well as the transfer of the organism from hamburger patties to produce via common food-handling practices. Here, we extended our earlier studies to include possible cross-contamination via handling of ground beef and transfer to lettuce from human handling and cutting boards.

Previous studies by others have focused on various aspects of cross-contamination, including the role of gloves and cutting boards in the promotion or inhibition of pathogen attachment and growth. Miller et al. (13) found that the levels of attachment of beef bacterial microbiota to polyethylene and wooden cutting boards were similar. In this study, chemical cleaners removed similar numbers of bacteria relative to water alone. Ak et al. (1) showed that fewer $E$. coli $\mathrm{O} 157: \mathrm{H} 7$ cells were recovered from wooden boards than from plastic boards; the extent of this difference increased with incubation time. The pathogen was recovered from plastic cutting boards after $12 \mathrm{~h}$, and bacteria 
multiplied on plastic cutting board surfaces when applied in filter-sterilized chicken juice. High humidity was necessary for the persistence and multiplication of bacteria on plastic cutting boards (2).

Transfer rates among hands, foods (including chicken and lettuce), and kitchen surfaces were studied by Chen et al. (7), who used a nonpathogenic indicator, Enterobacter aerogenes, to provide data for risk management efforts. These investigators also examined transfer rates from food to both gloved and bare hands. Although gloves provided a barrier to bacterial transfer, polyethylene gloves were permeable to bacteria (14).

Here, we used a relevant lettuce outbreak strain of $E$. coli $\mathrm{O} 157: \mathrm{H} 7$ to quantitate bacterial survival in ground beef and subsequent transfer of bacteria to hands and cutting board surfaces. We also investigated the cross-contamination of iceberg lettuce by contaminated hands and cutting boards and the potential for produce contamination after repeated contact with cutting boards.

\section{MATERIALS AND METHODS}

Bacterial strains and growth conditions. E. coli $\mathrm{O} 157: \mathrm{H} 7$ strain F6460 was used throughout this study. This strain, originally isolated from patients during a 1999 lettuce outbreak linked to a Nebraska restaurant, was obtained from Timothy Barrett (Centers for Disease Control, Atlanta, Ga.) and Thomas Safranek (Nebraska Health and Human Services System, Lincoln, Nebr.). The (nonpathogenic) $E$. coli normal flora strain 97A-5984 was obtained from Sharon Abbott and Michael Janda (California State Department of Health Services, Microbial Diseases Laboratory, Berkeley, Calif.). Nalidixic acid-resistant strains F6460 Nal ${ }^{\mathrm{R}}$ and 97A-5984 Nal${ }^{\mathrm{R}}$ were isolated as described previously (18). Bacteria were stored at $-80^{\circ} \mathrm{C}$ in Luria-Bertani (LB) broth (Difco Laboratories, Detroit, Mich.) containing 25\% (vol/vol) glycerol. E. coli $\mathrm{O} 157: \mathrm{H} 7$ strains were grown on LB agar plates or in LB broth at $37^{\circ} \mathrm{C}$. When appropriate, nalidixic acid (Sigma Chemical Co., St. Louis, Mo.) was added to achieve a final concentration of $20 \mu \mathrm{g} / \mathrm{ml}$.

\section{E. coli 0157:H7 cross-contamination experiments. All} cross-contamination experiments were performed three or four times; samples were tested in triplicate unless otherwise indicated.

Transfer of $E$. coli O157:H7 from contaminated ground beef to fingers via human handling. E. coli strains $\mathrm{F} 6460 \mathrm{Nal}^{\mathrm{R}}$ and $97 \mathrm{~A}-5984 \mathrm{Nal}^{\mathrm{R}}$ were grown overnight (for 12 to $16 \mathrm{~h}$ ) at $37^{\circ} \mathrm{C}$ in LB broth containing $20 \mu \mathrm{g}$ of nalidixic acid per ml. Tenfold serial dilutions of bacteria were prepared with phosphatebuffered saline (PBS) and held in test tubes for 2 days at room temperature (ca. $25^{\circ} \mathrm{C}$ ) to starve the bacteria, thus simulating a realistic inoculum. Fresh 80 and $93 \%$ lean ground beef samples and iceberg lettuce (Lactuca sativa L.) were obtained from a local supermarket. Both the ground beef and the lettuce were stored at $4^{\circ} \mathrm{C}$ and used within 12 to $16 \mathrm{~h}$ of purchase. Ground beef was divided into 0.25-lb (113-g) samples and inoculated with $2.2 \mathrm{ml}$ of the starved E. coli O157:H7 culture. Bacteria were mixed into the ground beef by hand for $1 \mathrm{~min}$ with the use of latex gloves (Evolution One, Microflex Medical Corp., Reno, Nev.). The gloved fingers of each hand were gently pressed onto LB agar plates containing nalidixic acid, which were incubated overnight at $37^{\circ} \mathrm{C}$ before the enumeration of bacteria. Gloves were changed between samples.

Alternatively, ground beef samples were inoculated with $E$. coli normal flora strain $97 \mathrm{~A}-5984 \mathrm{Nal}^{\mathrm{R}}$ and mixed with gloved or bare hands as described above. Contaminated fingers were pressed onto LB agar containing nalidixic acid and incubated overnight at $37^{\circ} \mathrm{C}$ before the enumeration of bacteria. Gloves were changed after each sample, and bare hands were washed thoroughly with a 50\% solution of Ultra Joy concentrated dishwashing detergent (Proctor and Gamble, Cincinnati, Ohio) and warm tap water between samples.

E. coli 0157:H7 growth and survival in ground beef. Ground beef was inoculated with E. coli $0157: \mathrm{H} 7$ strain F6460 $\mathrm{Nal}^{\mathrm{R}}$ as described above and divided into halves, with each half weighing ca. $56.5 \mathrm{~g}$. One 5-g sample from the first inoculated half was analyzed immediately, and a 5-g sample from the second half was analyzed following overnight storage $(16 \mathrm{~h})$ at $4{ }^{\circ} \mathrm{C}$ or at room temperature (ca. $25^{\circ} \mathrm{C}$ ). The remainder of each half patty was reserved for cutting board transfer experiments (see below). Ground beef samples were placed in a Whirl-Pak bag (Nasco, Fort Atkinson, Wis.) containing $25 \mathrm{ml}$ of sterile peptone water and homogenized in a Stomacher 80 Biomaster (Seward Limited, London, UK) for $1 \mathrm{~min}$ at high speed. Homogenates were filtered through sterile glass wool, and duplicate samples were spiral plated (Wasp II Spiral Plater, DW Scientific, West Yorkshire, UK) onto LB agar plates containing nalidixic acid. After overnight (12- to 16-h) incubation at $37^{\circ} \mathrm{C}$, colonies were enumerated with an automated plate counter (Protoc, Synoptics, Cambridge, UK).

Transfer of $E$. coli O157:H7 from contaminated fingers to lettuce via human handling. Ground beef was divided and hand mixed with E. coli $\mathrm{O} 157: \mathrm{H} 7$ strain $\mathrm{F} 6460 \mathrm{Nal}^{\mathrm{R}}$ for $1 \mathrm{~min}$ with the use of latex gloves as described above. A 7-g sample of lettuce was then handled with contaminated gloved fingers for 15 s. Gloves were changed after the handling of each sample. Lettuce samples were homogenized in $35 \mathrm{ml}$ of sterile peptone water and plated on selective medium, and the associated pathogens were enumerated as described above.

Transfer of $E$. coli 0157:H7 from contaminated hamburger patties to cutting boards and subsequent rinsing of boards. Ground beef was hand mixed with $E$. coli $\mathrm{O} 157: \mathrm{H} 7$ strain F6460 $\mathrm{Nal}^{\mathrm{R}}$ for $1 \mathrm{~min}$ with the use of latex gloves and divided as described above. The inoculated beef was pressed firmly onto a sterile polyethylene cutting board (America Cooks, Robinson Knife Co., Buffalo, N.Y.) for ca. 5 to $10 \mathrm{~s}$ to form hamburger patties ca. $8 \mathrm{~cm}$ in diameter and removed. Cutting boards were tested for $E$. coli cross-contamination immediately or after overnight storage ( $16 \mathrm{~h}$, uncovered) at room temperature (ca. $\left.25^{\circ} \mathrm{C}\right)$. A sterile cotton swab was dipped into $1 \mathrm{ml}$ of sterile PBS, rubbed for $10 \mathrm{~s}$ over the entire cutting board area that had been in contact with the contaminated hamburger, and then vortexed in PBS. The swab was then pressed along the edge of the tube to remove most of the remaining PBS. Duplicate cutting board swab samples were plated onto LB agar containing nalidixic acid, incubated, and enumerated as described above.

A cutting board rinsing experiment was carried out by inoculating ground beef and forming hamburger patties on cutting boards as described above. Contaminated boards were rinsed for $15 \mathrm{~s}$ with warm (ca. $35^{\circ} \mathrm{C}$ ) tap water at a medium flow rate of ca. 4 liters $/ \mathrm{min}$. Water was allowed to hit the board ca. $10 \mathrm{~cm}$ above the contaminated spot to rinse off associated bacteria. Pathogens remaining on cutting boards following the water rinse were enumerated as described above.

Transfer of $E$. coli $0157: H 7$ from contaminated cutting boards to successive lettuce pieces. Ground beef was inoculated with E. coli $\mathrm{O} 157: \mathrm{H} 7$ strain $\mathrm{F} 6460 \mathrm{Nal}^{\mathrm{R}}$, and hamburger patties 
were formed on sterile cutting boards as described above. The outer leaves of commercial iceberg lettuce heads were removed; the inner leaves were cut into 4 -g pieces (ca. 8 by $8 \mathrm{~cm}$ ) with a sterile knife and firmly pressed by hand onto the contaminated areas of cutting board surfaces for $5 \mathrm{~s}$. The pressure used to press lettuce onto the cutting boards was about the pressure that a food handler would exert to hold lettuce heads while chopping and was sufficient to deform the lettuce such that the lettuce made full contact with the board surface. Three pieces of lettuce were pressed in succession onto the same contaminated spot and processed immediately (for both nonstored cutting boards and cutting boards stored overnight at room temperature). An additional set of three lettuce pieces was immediately pressed onto contaminated cutting boards and then stored overnight at $4^{\circ} \mathrm{C}$ in sealed Ziploc bags (S. C. Johnson and Son, Inc., Racine, Wis.) before processing. Lettuce pieces were placed in Whirl-Pak bags containing 20 $\mathrm{ml}$ of sterile peptone water, homogenized, and plated, and bacteria were enumerated as described above.

Transfer of $E$. coli $0157: \mathrm{H7}$ from contaminated cutting boards to 25 lettuce pieces in succession. Ground beef was inoculated with E. coli $\mathrm{O} 157: \mathrm{H} 7$ strain $\mathrm{F} 6460 \mathrm{Nal}^{\mathrm{R}}$, and hamburger patties were formed on sterile cutting boards as described above. Twenty-five iceberg lettuce pieces ( 4 by $4 \mathrm{~cm}$ ) were firmly pressed in succession for $5 \mathrm{~s}$ onto the same contaminated spot on the cutting board. Five $1-\mathrm{cm}^{2}$ pieces were cut from the center of each pressed lettuce piece with a razor (to facilitate the placement of lettuce into the test tube). All five pieces cut from the same pressed lettuce sample were placed into a single test tube containing LB broth supplemented with nalidixic acid, and the tubes were incubated on a roller drum overnight at $37^{\circ} \mathrm{C}$ to select for the growth of E. coli O157:H7 strain F6460 Nal ${ }^{\mathrm{R}}$ (25 tubes for each set of 25 leaves pressed against a single contaminated spot on the cutting board). Three bacterial cultures from each set of leaves positive for growth in selective media were confirmed to be E. coli $\mathrm{O} 157: \mathrm{H} 7$ cultures by polymerase chain reaction (PCR) analysis with primers specific for eae (8), the gene encoding the intimin outer-membrane protein $(4,10)$.

Analysis of ground beef normal flora. For each trial, two 25 -g samples of each ground beef type ( $80 \%$ lean or $93 \%$ lean) were placed in sterile 400-ml filter bags (Spiral Biotech, Norwood, Mass.) and diluted 1:10 (Dilumat3, AES Laboratories, Combourg, France) in $0.1 \%$ sterile peptone (Difco). Each sample was homogenized in a Stomacher 400 (Interscience, Switzerland) at high speed for $2 \mathrm{~min}$. Serial dilutions were made, spiral plated in duplicate onto plate count agar (Difco), and incubated at $30^{\circ} \mathrm{C}$ for $24 \mathrm{~h}$. After incubation, five colonies were picked from each plate, restreaked for isolation onto plate count agar, and incubated at $30^{\circ} \mathrm{C}$ for $24 \mathrm{hr}$. A MacFarland standard was prepared from the isolated colonies on each of the plates, and a corresponding oxidase test (for gram-negative organisms) or catalase test (for grampositive organisms) was performed. Each isolated organism was inoculated into a test card and loaded into the Vitek 32 apparatus (bioMerieux, Inc., Hazelwood, Mo.) for identification according to the manufacturer's instructions. PCR analysis was performed on three colonies identified as Yersinia spp. but undefined at the species level. PCR reactions were carried out with primers specific for the 16s rRNA and ail genes. Further analysis was conducted with the Biolog MicroLog (Release 4.0, Biolog Microlog, Hayward, Calif.) system according to the manufacturer's instructions. Three E. coli colonies were analyzed by PCR with primers specific for eae (8).
Fat and moisture analysis of ground beef. Approximately $4 \mathrm{~g}$ of ground beef was placed in a Whatman no. 2 filter paper packet. The packet was oven dried overnight at $100^{\circ} \mathrm{C}$ (Napco no. 5861, Precision Scientific, Chicago, Ill.) to determine the percentage of moisture $(=$ [wet weight - dry weight $]$ /wet weight $\times$ 100). Dried samples were then extracted with petroleum ether (certified ACS, Fisher Scientific, Fair Lawn, N.J.) in a Soxhlet apparatus (Corning, Inc., Acton, Mass.) (3). Samples were subjected to six ether flushes (ca. 12 to $16 \mathrm{~h}$ total extraction time), air dried to evaporate ether vapors, and then oven dried at $100^{\circ} \mathrm{C}$ for $5 \mathrm{~h}$ to remove traces of moisture. The percentage of fat was calculated as (dry weight - extracted weight)/wet weight $\times 100$. Six replicates were tested for each sample.

Statistics. Data were analyzed with the use of the General Linear Model procedure of the Statistical Analysis System (Version 7, SAS, Cary, N.C.) (15). Treatments were arranged in a randomized complete block design, with $X$ and $Y$ being used as main effects. Means were separated with Duncan's multiple-range test, and correlations between variables were determined with Pearson's correlation factors. Differences were considered significant at $P \leq 0.05$.

\section{RESULTS}

Pathogen contamination and temperature abuse of ground beef result in subsequent produce contamination via human handling. To determine the effect of temperature abuse on E. coli O157:H7 growth in contaminated ground beef and on the potential for the subsequent transfer of bacteria to produce via human handling, we carried out cross-contamination studies. Fresh commercial 80 and $93 \%$ lean ground beef and iceberg lettuce were used for these studies. To begin these studies, we analyzed commercial ground beef for fat and moisture content, as well as for the possible presence of bacterial pathogens, including $E$. coli O157:H7. Fat and moisture analysis of ground beef sampled on 6 days revealed means of $64.15 \% \pm 1.98 \%$ moisture and $82.36 \% \pm 1.64 \%$ lean tissue for ground beef labeled $80 \%$ lean and means of $73.06 \% \pm 1.83 \%$ moisture and $92.47 \% \pm 0.91 \%$ lean tissue for ground beef labeled $93 \%$ lean (data not shown). The normal microfloras of the ground beef were characterized with the use of a Vitek 32 apparatus. The identification of 79 colonies isolated from $80 \%$ lean beef revealed $62 \%$ Pseudomonas spp., $14 \%$ Streptococcus spp., 7\% Staphylococcus spp., 5\% Yersinia intermedia, 4\% Enterococcus spp., 3\% Yersinia spp., 2\% Aeromonas spp., $1 \%$ E. coli, and 1\% Alcaligenes spp. Seventy-five colonies isolated from $93 \%$ lean ground beef were characterized as 67\% Pseudomonas spp., 23\% Streptococcus spp., 4\% Yersinia spp., 2\% Staphylococcus spp., 1\% Listeria spp., $1 \%$ Aeromonas spp., and 1\% Corynebacterium spp. PCR analysis was conducted for three colonies identified as Yersinia but not defined at the species level. Results obtained with primers specific for the 16s rRNA and ail (attachment invasion locus) genes (20) suggested that these colonies were not pathogenic Yersinia enterocolitica colonies. One of these colonies was confirmed to be a Yersinia frederiksenii colony with the Biolog MicroLog system. Three E. coli colonies tested negative for the presence of the eae gene by PCR analysis (8), suggesting that these colonies were not $E$. coli $\mathrm{O} 157: \mathrm{H} 7$ colonies. 
TABLE 1. Growth and survival of E. coli O157:H7 strain F6460 Nal ${ }^{R}$ in ground beef ${ }^{a}$

\begin{tabular}{|c|c|c|c|c|}
\hline $\begin{array}{c}\text { Initial } \\
\text { inoculum } \\
\text { level } \\
\text { (CFU/g of } \\
\text { ground beef) }\end{array}$ & $\begin{array}{c}\% \text { leanness } \\
\text { of beef }\end{array}$ & $\begin{array}{l}\text { Incubation } \\
\text { temperature }\end{array}$ & \multicolumn{2}{|c|}{ E. coli $\mathrm{O} 157: \mathrm{H} 7$ count (CFU/g of ground beef) } \\
\hline \multirow[t]{2}{*}{$4 \times 10^{5}$} & 93 & $4^{\circ} \mathrm{C}$ & $2.2( \pm 0.1) \times 10^{5}$ & $2.5( \pm 0.8) \times 10^{5}$ \\
\hline & 80 & $4^{\circ} \mathrm{C}$ & $2.5( \pm 0.3) \times 10^{5}$ & $3.0( \pm 0.6) \times 10^{5}$ \\
\hline \multirow[t]{2}{*}{$4 \times 10^{4}$} & 93 & $4^{\circ} \mathrm{C}$ & $2.3( \pm 0.6) \times 10^{4}$ & $2.9( \pm 0.3) \times 10^{4}$ \\
\hline & 80 & $4^{\circ} \mathrm{C}$ & $2.8( \pm 0.7) \times 10^{4}$ & $3.4( \pm 0.4) \times 10^{4}$ \\
\hline \multirow[t]{2}{*}{$6 \times 10^{2}$} & 93 & RT & $5.8( \pm 4.3) \times 10^{2}$ & $9.2( \pm 5.8) \times 10^{4}$ \\
\hline & 80 & RT & $1.8( \pm 0.4) \times 10^{3}$ & $1.2( \pm 0.3) \times 10^{5}$ \\
\hline
\end{tabular}

${ }^{a}$ Ground beef (93 or $80 \%$ lean) was inoculated with strain $\mathrm{F} 6460 \mathrm{Nal}^{\mathrm{R}}$ and formed into patties. Beef was sampled immediately (0 h) and after storage for $16 \mathrm{~h}$ at $4^{\circ} \mathrm{C}$ or room temperature (RT), and pathogens were then enumerated. Three samples were analyzed for each treatment; means and standard errors of the mean are given. The limit of detection was $120 \mathrm{CFU} / \mathrm{g}$ of ground beef.

Ground beef patties (113 g [ca. $0.25 \mathrm{lb}])$ were inoculated with E. coli $\mathrm{O} 157: \mathrm{H} 7$ outbreak strain $\mathrm{F} 6460 \mathrm{Nal}^{\mathrm{R}}$ and stored for 12 to $16 \mathrm{~h}$ at $4^{\circ} \mathrm{C}$ or at room temperature (ca. $28^{\circ} \mathrm{C}$ ). Storage at $4^{\circ} \mathrm{C}$ resulted in no significant pathogen growth at two bacterial inoculation levels and two different beef fat levels (Table 1) $(P>0.05$ for 93 versus $80 \%$ lean beef and for 0 versus $16 \mathrm{~h}$ ). However, overnight storage at room temperature allowed significant bacterial multiplication in all samples tested (Table 1$)(P=0.0056$ for 0 versus $16 \mathrm{~h})$. Ground beef inoculated with $6 \times 10^{4} \mathrm{CFU} / \mathrm{g}$ displayed 2.04 and $3.38 \log$ units of pathogen growth after 16 $\mathrm{h}$ of storage at room temperature in 93 and $80 \%$ lean beef, respectively. A lower inoculum level $\left(6 \times 10^{2} \mathrm{CFU} / \mathrm{g}\right) \mathrm{re}-$ sulted in 2.20 and $1.84 \log$ units of growth in 93 and $80 \%$

TABLE 2. Transfer of E. coli from contaminated ground beef to fingers via human handling ${ }^{a}$

\begin{tabular}{clcc}
\hline $\begin{array}{c}\text { Initial } \\
\text { inoculum } \\
\text { level } \\
(\text { CFU/g of } \\
\text { ground beef })\end{array}$ & $\begin{array}{c}\text { E. coli } \\
\text { strain }\end{array}$ & $\begin{array}{c}\% \\
\text { leanness } \\
\text { of beef }\end{array}$ & $\begin{array}{c}\text { Level of } E \text {. coli } \\
\text { recovered } \\
\text { (CFU/10 } \\
\text { fingers })\end{array}$ \\
\hline $4 \times 10^{4}$ & F6460 Nal & 93 & $6.2( \pm 0.2) \times 10^{2}$ \\
& F6460 Nal & 80 & $5.1( \pm 0.8) \times 10^{2}$ \\
$4 \times 10^{3}$ & F6460 Nal & 93 & $2.5( \pm 0.2) \times 10^{2}$ \\
& F6460 Nal & 80 & $2.0( \pm 0.6) \times 10^{2}$ \\
$7 \times 10^{\mathrm{R}}$ & $97 \mathrm{~A}-5984 \mathrm{Nal}^{\mathrm{R}}$ & 93 & $4.2( \pm 0.2) \times 10^{2}$ \\
& $97 \mathrm{~A}-5984 \mathrm{Nal}^{\mathrm{R}}$ & 80 & $6.2( \pm 0.7) \times 10^{2}$ \\
$7 \times 10^{3}$ & $97 \mathrm{~A}-5984 \mathrm{Nal}^{\mathrm{R}}$ & 93 & $5.0( \pm 0.1) \times 10^{2}$ \\
& $97 \mathrm{~A}-5984 \mathrm{Nal}^{\mathrm{R}}$ & 80 & $4.4( \pm 0.1) \times 10^{2}$ \\
\hline
\end{tabular}

${ }^{a}$ Ground beef (93 or $80 \%$ lean) was inoculate with bacteria and formed into patties. Hands covered with latex gloves were used to inoculate beef with E. coli $\mathrm{O} 157: \mathrm{H} 7$ strain $\mathrm{F} 6460 \mathrm{Nal}^{\mathrm{R}}$, and bare hands were used to inoculate beef with the (nonpathogenic) normal human flora strain 97A-5984 Nal${ }^{\mathrm{R}}$. Bacteria were then recovered from the 10 contaminated fingers of the two inoculating hands and quantitated. Three samples were analyzed for each treatment; means and standard errors of the mean are given. The limit of detection was $1 \mathrm{CFU}$ per 10 fingers. lean beef, respectively, under the same storage conditions (Table 1).

To determine the capacity of $E$. coli $\mathrm{O} 157: \mathrm{H} 7$ for transfer from contaminated beef to produce via human handling, we first quantitated bacteria associated with gloved and nongloved hands after the manual formation of a hamburger patty from contaminated ground beef for $1 \mathrm{~min}$. Lettuce was then subjected to handling with contaminated hands. The handling of ground beef containing bacteria at levels of $4 \times 10^{4}$ and $4 \times 10^{3} \mathrm{CFU} / \mathrm{g}$ resulted in averages of 2.76 and $2.35 \log$ units of $E$. coli $\mathrm{O} 157: \mathrm{H} 7$ associated with gloved fingers, respectively (Table 2). There was no significant difference between levels of pathogen transfer for 93 and $80 \%$ lean beef $(P=0.910)$. Similar levels of transfer to gloved fingers (data not shown) and bare hands (Table 2) were seen for $E$. coli normal flora strain $97 \mathrm{~A}-5984 \mathrm{Nal}^{\mathrm{R}}$. Again, beef fat content did not affect this transfer rate $(P$ $=0.1635$ for 93 versus $80 \%$ lean beef). Human handling of lettuce with contaminated gloved fingers for ca. $15 \mathrm{~s}$ resulted in the transfer of ca. 10\% E. coli $\mathrm{O} 157: \mathrm{H} 7$ from contaminated ground beef to lettuce for the inoculum level $9.6 \times 10^{4} \mathrm{CFU} / \mathrm{g}$ and in the transfer of ca. $1 \% \mathrm{E}$. coli O157:H7 from contaminated ground beef to lettuce for the inoculum level $9.6 \times 10^{3} \mathrm{CFU} / \mathrm{g}$ (Table 3). Beef fat content did not significantly affect this transfer rate overall $(P=$ 0.5500 for 93 versus $80 \%$ lean beef for all samples tested).

Pathogens transferred to cutting boards and produce persist despite storage and repeated contact. Contact of hamburger patties containing $4 \times 10^{5} \mathrm{CFU}$ of $E$. coli $\mathrm{O} 157: \mathrm{H} 7$ per $\mathrm{g}$ with plastic cutting board surfaces for 5 to $10 \mathrm{~s}$ resulted in significant transfer of bacteria to the board surfaces (with an average transfer level of ca. $7 \times$ $10^{3} \mathrm{CFU} / 50 \mathrm{~cm}^{2}$ ) (Fig. 1A). Overnight storage of contaminated boards at room temperature (ca. $25^{\circ} \mathrm{C}$ ) significantly decreased the numbers of recoverable pathogens on cutting boards by an average of $1 \log$ CFU in all cases (Fig. 1A) $(P=0.0036$ for 0 versus $16 \mathrm{~h}$ of storage). However, numbers of bacteria cultured from cutting boards remained at levels sufficient to cause human disease (an average of 7.09 
TABLE 3. Transfer of E. coli O157:H7 from contaminated gloved fingers to lettuce ${ }^{a}$

\begin{tabular}{ccc}
\hline $\begin{array}{c}\text { Initial } \\
\text { inoculum level } \\
\text { (CFU/g of } \\
\text { ground beef })\end{array}$ & $\begin{array}{c}\text { \% leanness } \\
\text { of beef }\end{array}$ & $\begin{array}{c}\text { Level of } E \text {. coli } \\
\text { O157:H7 recovered } \\
(\text { CFU/g of lettuce })\end{array}$ \\
\hline $9.6 \times 10^{4}$ & 93 & $1.0( \pm 0.3) \times 10^{4}$ \\
& 80 & $1.3( \pm 0.3) \times 10^{4}$ \\
$9.6 \times 10^{3}$ & 93 & $5.9( \pm 1.3) \times 10^{1}$ \\
& 80 & $9.4( \pm 0.4) \times 10^{1}$ \\
\hline
\end{tabular}

${ }^{a}$ Ground beef was hand mixed with $E$. coli $\mathrm{O} 157: \mathrm{H} 7$ strain F6460 $\mathrm{Nal}^{\mathrm{R}}$ with the use of latex gloves. Commercial iceberg lettuce was handled for $15 \mathrm{~s}$ with contaminated gloved fingers, and the pathogens associated with the lettuce were then quantitated. Four samples were analyzed for each treatment; means and standard errors of the mean are given. The limit of detection was 120 $\mathrm{CFU} / \mathrm{g}$ of lettuce.

$\times 10^{2} \mathrm{CFU}$ for the dose $4 \times 10^{5} \mathrm{CFU}$ and an average of $3.55 \times 10^{1}$ for the dose $\left.4 \times 10^{4} \mathrm{CFU}\right)$.

The number of pathogens dissociated from cutting boards after a 15 -s rinse with warm $\left(35^{\circ} \mathrm{C}\right)$ water was not significantly different from the number dissociated from nonrinsed boards (Fig. 1B) $(P=0.0550$ for all samples tested over time). A rinse applied immediately after bacterial contamination resulted in an average $0.23-\log$ decrease in the number of pathogens associated with cutting boards, with an average of $39.8 \%$ of the pathogens being removed. Inoculation of cutting boards followed by $16 \mathrm{~h}$ of storage prior to rinsing resulted in the disassociation of an average of $0.39 \log$ units $(58.6 \%)$ of E. coli. Again, the numbers of pathogens remaining on cutting board surfaces following $16 \mathrm{~h}$ of storage and a warm-water rinse were sufficient to cause disease $(9,17)$.

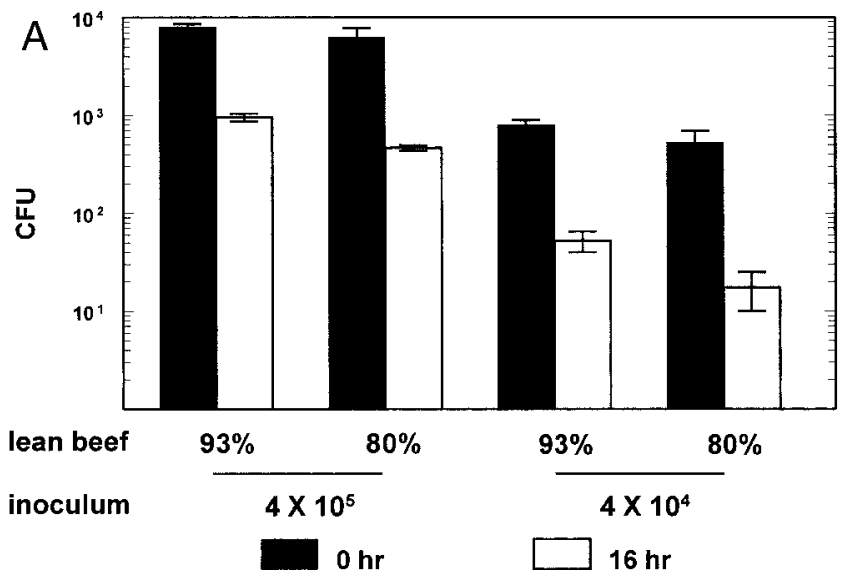

To quantitate the transfer of E. coli O157:H7 from contaminated cutting boards to lettuce, three leaves were pressed in succession onto a single contaminated area of the board immediately after the boards were exposed to tainted beef patties and after room-temperature (ca. $25^{\circ} \mathrm{C}$ ) storage of contaminated boards for $16 \mathrm{~h}$. An additional set of leaves was pressed onto boards immediately after contamination by beef patties and stored overnight at $4^{\circ} \mathrm{C}$ before the enumeration of pathogens. The difference between the numbers of pathogens transferred to the first pressed leaves and the numbers transferred to third leaves was, on average, $0.47 \log$ CFU/g of lettuce (Fig. 2A and 2B). The total number of pathogens recovered from the three lettuce leaves combined was similar to the numbers of pathogens swabbed from contaminated boards (Fig. 2A and 2B versus Fig. 1A for the inoculum level $\left.4 \times 10^{5} \mathrm{CFU}\right)$. We recovered $2.05 \times 10^{3} \mathrm{CFU}$ of pathogens from three lettuce leaves applied in succession to a $50-\mathrm{cm}^{2}$ area on the board containing $8.03 \times 10^{3} \mathrm{CFU}$. After overnight incubation, $9.53 \times 10^{2} \mathrm{CFU}$ was cultured from cutting board swabs, while three pressed leaves were found to carry $4.67 \times 10^{2}$ total CFU (93\% lean beef). Similar results were obtained when $80 \%$ lean beef was used to contaminate cutting boards (data not shown). Overall, the numbers of pathogens transferred to the first pressed leaves were significantly larger than the numbers transferred to the second and third leaves (Fig. 2A and 2B) $(P=0.0018$ for the numbers of pathogens associated with first leaves versus the numbers associated with second or third leaves under all conditions tested). However, there was no significant difference in the numbers of pathogens transferred to second leaves and the numbers transferred to third leaves $(P>0.05)$. There was no significant difference between the numbers of pathogens recovered from leaves pressed immediately after contamination and enumerated immediately and the numbers re-

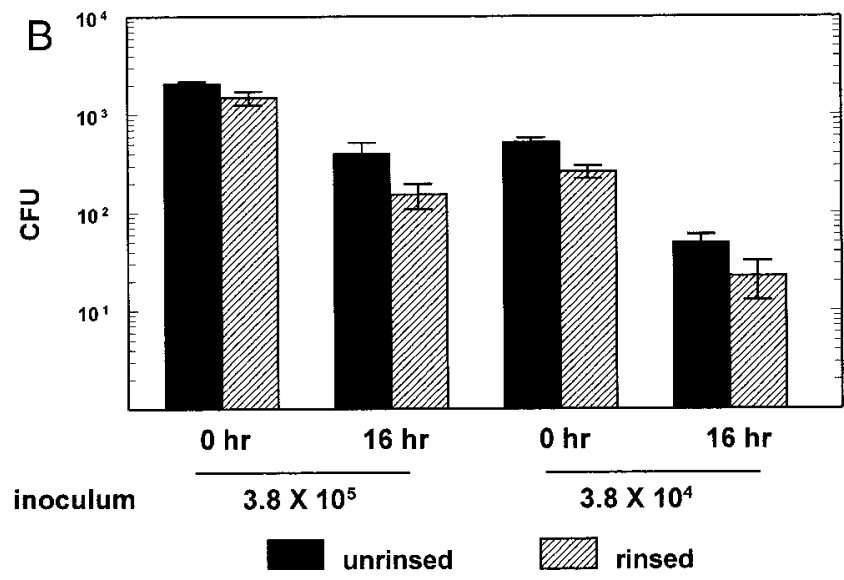

FIGURE 1. Transfer of E. coli O157:H7 from contaminated ground beef patties to cutting boards via human handling and subsequent rinsing of boards. Ground beef (93 or 80\% lean) was inoculated with E. coli O157:H7 strain F6460 Nal ${ }^{R}$; inoculum levels (CFU/g of ground beef) are indicated. Hamburger patties were formed and gently pressed onto polyethylene cutting boards. The values shown on the $\mathrm{y}$ axis represent the total numbers of $\mathrm{E}$. coli $\mathrm{CFU}$ recovered from a $\sim 50-\mathrm{cm}^{2}$ area of the cutting board contaminated by the inoculated beef patties. (A) Pathogens associated with boards were quantitated immediately (solid bars) and after storage at room temperature ( $\mathrm{ca} .25^{\circ} \mathrm{C}$ ) for $16 \mathrm{~h}$ (open bars). (B) For $93 \%$ lean beef only, pathogens associated with boards were enumerated immediately (solid bars, time indicated), after a 16-h storage period (solid bars, time indicated), and after a 15-s rinse with warm tap water (ca. $35^{\circ} \mathrm{C}$ ) (cross-hatched bars, time indicated). Three or four samples were tested for each datum point; the datum points shown represent means and standard errors of the means. The limit of detection was $10 \mathrm{CFU}$. 

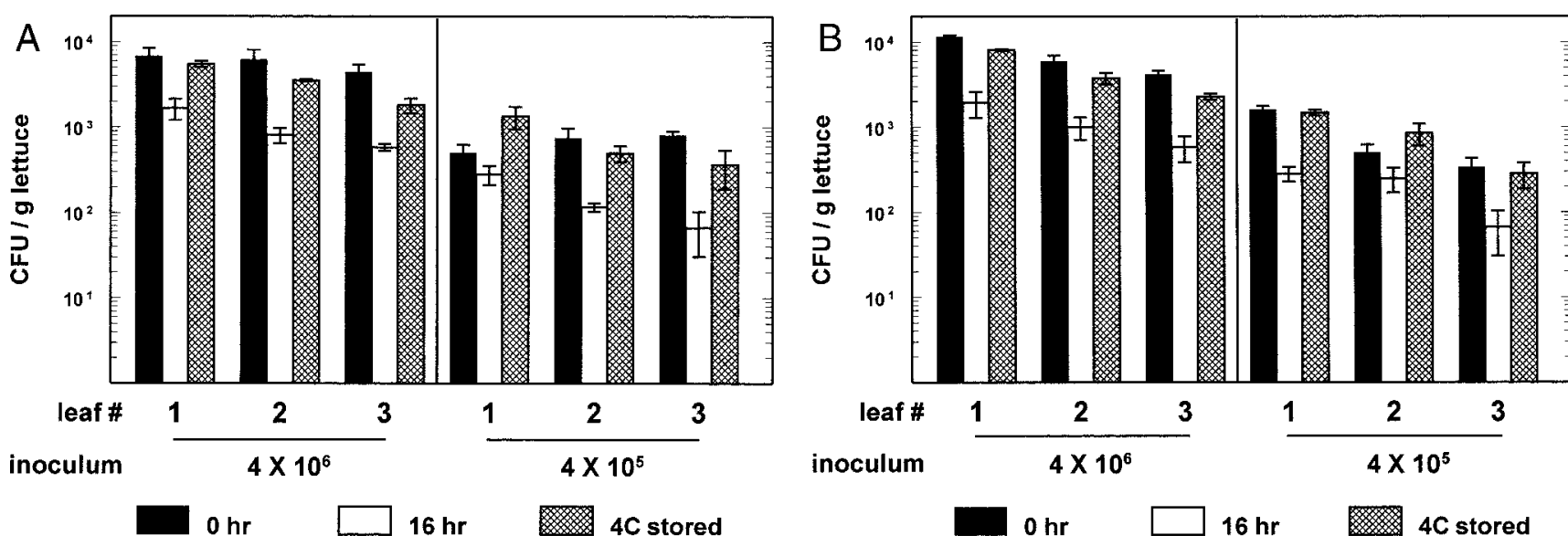

FIGURE 2. Transfer of E. coli O157:H7 from contaminated cutting boards to lettuce pieces pressed to the boards in succession. (A) Ninety-three percent lean and (B) 80\% lean ground beef was inoculated with E. coli O157:H7 strain F6460 Nal ${ }^{R}$; inoculum levels (CFU/g of ground beef) are indicated. Hamburger patties were formed and gently pressed onto polyethylene cutting boards. Three lettuce leaves were pressed in succession onto one contaminated area of the board immediately (solid bars) and after storage of the boards at room temperature $\left(\mathrm{ca} .25^{\circ} \mathrm{C}\right)$ for $16 \mathrm{~h}$ (open bars). Another set of three lettuce pieces were pressed to board surfaces immediately after beef contamination and analyzed for the enumeration of pathogens following overnight storage of the lettuce in bags at $4{ }^{\circ} \mathrm{C}$ (cross-hatched bars). Three samples were tested for each datum point; the datum points shown represent means and standard errors of the means. The limit of detection was $120 \mathrm{CFU} / \mathrm{g}$ of lettuce.

covered following overnight storage at $4^{\circ} \mathrm{C}(P>0.05)$. However, significantly smaller numbers of pathogens were transferred to leaves pressed to boards stored at room temperature $\left(\mathrm{ca} .28^{\circ} \mathrm{C}\right)$ for $16 \mathrm{~h}$ prior to contact with lettuce $(P$ $<0.0001)$. The beef fat content did not significantly affect the numbers of pathogens transferred to lettuce leaves $(P$ $=0.4894$ ).

To determine the incidence of pathogen transfer after repeated contact with a contaminated cutting board surface, 25 lettuce pieces were pressed in succession onto a single contaminated spot on the board. Individual lettuce pieces were then cultured in separate tubes containing a selective medium to test for the presence of the pathogen. An inoculum level of $9.8 \times 10^{2} \mathrm{CFU}$ on a $50-\mathrm{cm}^{2}$ area of the cutting boards (determined by swabbing) resulted in an average transfer incidence of $90 \%$, with the 23rd and 25th lettuce leaves becoming contaminated in two different experiments (Table 4). The transfer of pathogens was more sporadic at an inoculum level of $1.25 \times 10^{2} \mathrm{CFU}$. At this dose, an average of $46 \%$ of the leaves were contaminated with $E$. coli $\mathrm{O} 157: \mathrm{H} 7$; the 25th leaf was among these contaminated leaves in one experiment. Most lettuce leaves remained uncontaminated at the lowest dose tested $(1.75 \times$ $\left.10^{1} \mathrm{CFU}\right)$, although the 11 th leaf tested positive in two trials.

For each experiment, three contaminated lettuce cultures testing positive for the growth of a Nal strain in LB broth were subjected to further PCR analysis with probes specific for eae (8) to verify that the cultures were those of strain F6460 Nal (16 samples altogether, with 1 sample tested for an inoculum level of $1.75 \times 10^{1} \mathrm{CFU} / \mathrm{g}$ [trial 2]). All lettuce pieces testing positive for growth in nalidixic acid amplified DNA fragments of the appropriate sizes for the eae primers used, suggesting that these strains were indeed E. coli $\mathrm{O} 157: \mathrm{H7}$ strains (data not shown). No DNA was amplified from the negative controls (lettuce pressed to uninoculated spots on cutting boards) when these eae primers were used.

\section{DISCUSSION}

In this study, we showed that small numbers of $E$. coli O157:H7 can be transferred from contaminated plastic cutting boards to cut lettuce pieces even after successive pieces of lettuce have come in contact with the chopping surface. Although the method used to determine bacterial numbers on cutting boards, which involves the use of a cotton swab, underestimates pathogen numbers, it is remarkable that pathogens were transferred to the 11th leaf exposed to a contaminated cutting board containing $1.75 \times 10^{1} \mathrm{CFU}$ on a $50-\mathrm{cm}^{2}$ area in two independent experiments. In addition, $46 \%$ of lettuce leaves, including the 25 th exposed leaf, were cross-contaminated with the pathogen, when an inoculum level of $1.25 \times 10^{2} \mathrm{CFU}$ was used. Because the infectious dose of E. coli O157:H7 may be $<50$ organisms $(9,17)$, these observations stress the need for strict attention to food safety practices when potentially contaminated foods are handled coincidentally with foods to be eaten raw.

We observed that room-temperature storage of contaminated cutting boards decreased the number of recoverable pathogens by an average of $1 \log$ CFU. Although the pathogens may have entered a viable but nonculturable state that prevented recovery (6) or may have adhered strongly (possibly forming biofilms) to prevent recovery, at this juncture we have no indication that either of these situations occurred. It is possible that these organisms simply died. In contrast to our results, Ak et al. (1) observed overnight multiplication of E. coli $\mathrm{O} 157: \mathrm{H} 7$ when the pathogen was applied to plastic cutting boards. In their study, however, pathogens were suspended in filter-sterilized raw chicken juice, which undoubtedly provided nutrients to support the 
TABLE 4. Transfer of E. coli O157:H7 from cutting boards to 25 successive lettuce pieces

Result for inoculum level

(CFU on a $50-\mathrm{cm}^{2}$ area of a cutting board surface exposed to lettuce $)^{a}$

\begin{tabular}{|c|c|c|c|c|c|c|}
\hline Leaf no. & $\begin{array}{l}9.8( \pm 0.8) \\
\quad \times 10^{2}\end{array}$ & $\begin{array}{l}9.8( \pm 0.8) \\
\quad \times 10^{2}\end{array}$ & $\begin{array}{c}1.25( \pm 0.6) \\
\times 10^{2}\end{array}$ & $\begin{array}{c}1.25( \pm 0.6) \\
\times 10^{2}\end{array}$ & $\begin{array}{l}1.75( \pm 0.4) \\
\times 10^{1}\end{array}$ & $\begin{array}{c}1.75( \pm 0.4) \\
\times 10^{1}\end{array}$ \\
\hline 1 & + & + & + & + & + & - \\
\hline 2 & + & + & - & + & + & - \\
\hline 3 & + & + & + & + & + & - \\
\hline 4 & + & + & + & + & - & - \\
\hline 5 & + & + & + & + & - & - \\
\hline 6 & + & + & + & + & - & - \\
\hline 7 & + & + & + & - & - & - \\
\hline 8 & + & + & - & - & - & - \\
\hline 9 & + & + & + & - & - & - \\
\hline 10 & + & + & + & - & - & - \\
\hline 11 & + & - & + & - & + & + \\
\hline 12 & + & + & + & + & - & - \\
\hline 13 & - & + & - & + & - & - \\
\hline 14 & + & + & - & + & - & - \\
\hline 15 & + & + & + & - & - & - \\
\hline 16 & + & - & - & + & - & - \\
\hline 17 & + & + & - & - & - & - \\
\hline 18 & + & + & + & - & - & - \\
\hline 19 & + & + & - & - & - & - \\
\hline 20 & + & + & - & - & - & - \\
\hline 21 & + & + & - & - & - & - \\
\hline 22 & + & + & - & - & - & - \\
\hline 23 & + & + & - & - & - & - \\
\hline 24 & - & + & - & - & - & - \\
\hline 25 & - & + & + & - & - & - \\
\hline$\%$ positive & 88 & 92 & 52 & 40 & 16 & 4 \\
\hline
\end{tabular}

${ }^{a}$ Contaminated hamburger patties were pressed onto polyethylene cutting boards. Twenty-five lettuce pieces in succession were then pressed onto a single contaminated spot on the board, and five $1-\mathrm{cm}^{2}$ sections of each leaf were cultured in LB Nal broth overnight to determine whether the pathogen was present. A plus sign indicates that LB Nal cultures were positive for bacterial growth, and a minus sign indicates that no growth was observed following overnight culture. Each inoculum was tested four times; data shown are representative of two experiments per dose. Hamburger patties inoculated with $1.9 \times 10^{5} \mathrm{CFU}$ of E. coli O157:H7 strain F6460 Nal ${ }^{\mathrm{R}}$ per $g$ contained $1.31 \times 10^{5} \mathrm{CFU} / \mathrm{g}$ and resulted in the transfer of $9.8 \times 10^{2} \mathrm{CFU}$ to a $\sim 50-\mathrm{cm}^{2}$ area on the board (as determined by swabbing). Patties inoculated with $1.9 \times 10^{4} \mathrm{CFU}$ of $E$. coli $\mathrm{O} 157: \mathrm{H} 7$ strain F6460 Nal ${ }^{\mathrm{R}}$ per g contained $1.16 \times 10^{4} \mathrm{CFU} / \mathrm{g}$ and resulted in the transfer of $1.25 \times 10^{2} \mathrm{CFU}$ to the board. Patties inoculated with $1.9 \times 10^{3} \mathrm{CFU}$ of E. coli O157:H7 strain F6460 $\mathrm{Nal}^{\mathrm{R}}$ per g contained $3.28 \times 10^{3} \mathrm{CFU} / \mathrm{g}$ and resulted in the transfer of $1.75 \times 10^{1} \mathrm{CFU}$ to the board. Lettuce pieces exposed to uncontaminated cutting boards tested negative for growth in LB broth supplemented with nalidixic acid.

growth of the organisms. In addition, these authors found both the persistence and the multiplication of bacteria on plastic cutting boards to depend on the maintenance of high humidity (2). Our experiments were conducted with starved stationary-phase pathogens in a standard room atmosphere, with only typical hamburger patty residue remaining on the boards to simulate real-world cross-contamination conditions. Regardless, the capacity for the organism to withstand starvation, cross-contamination, overnight desiccation, and subsequent culture is noteworthy.

Following bacterial cross-contamination of plastic cutting boards or gloved hands, subsequent contamination of foods in contact with these surfaces occurred readily. In addition, significant numbers of pathogens remained on these boards after a 15-s warm-water rinse. This finding contrasts with the observations of Miller et al. (13), who reported the efficient removal of ground beef microbiota from cutting boards with water alone. Given that our experiments included beef microflora as well as E. coli O157: $\mathrm{H} 7$, the human pathogen may be better equipped for attachment to boards than the normal beef microflora is. We previously showed the inefficacy of water alone and highly chlorinated water in the removal of $E$. coli from cut leaf lettuce and lettuce seedlings $(18,19)$. We are currently investigating the molecular mechanisms through which this attachment occurs.

In conclusion, it is apparent that adherence to strict food safety practices during food handling is necessary for the prevention of pathogen cross-contamination from contaminated foods to kitchen equipment or other foods that may be eaten raw. Given the difficulty with which pathogens are removed from equipment surfaces and raw produce, adherence to good manufacturing practices and hazard analysis critical control point principles during produc- 
tion and processing, along with consumer and food-handler education, are critical to the maintenance of a wholesome food supply.

\section{ACKNOWLEDGMENTS}

We thank Ingrid Berlanger, Cheryl Mudd, and Janice Callahan for technical assistance, Verneta Gaskins for assistance with statistics, and Daniel Roberts for critical reading of the manuscript. We thank Timothy Barrett (Centers for Disease Control, Atlanta, Ga.) and Thomas Safranek (Nebraska Health and Human Services System) for the gift of strain F6460 and Sharon Abbott and Michael Janda (California State Department of Health Services, Microbial Diseases Laboratory, Berkeley, Calif.) for strain 97A-5984. This work was funded by the U.S. Department of Agriculture, Agricultural Research Service (CRIS projects 1275-42000-00200D and 1265-41420-002-00D).

\section{REFERENCES}

1. Ak, N. O., D. O. Cliver, and C. W. Kaspar. 1994. Cutting boards of plastic and wood contaminated experimentally with bacteria. J. Food Prot. 57:16-22.

2. Ak, N. O., D. O. Cliver, and C. W. Kaspar. 1994. Decontamination of plastic and wooden cutting boards for kitchen use. J. Food Prot. 57:23-30.

3. Association of Official Analytical Chemists. 1990. Association of Official Analytical Chemists official methods of analysis, 15th ed. Association of Official Analytical Chemists, Washington, D.C.

4. Beebakhee, G., M. Louie, J. De Azavedo, and J. Brunton. 1992. Cloning and nucleotide sequence of the eae gene homologue from enterohemorrhagic Escherichia coli serotype 0157:H7. FEMS Microbiol. Lett. 70:63-68.

5. Beuchat, L. R. 1996. Pathogenic microorganisms associated with fresh produce. J. Food Prot. 59:204-216.

6. Byrd, J. J., H. S. Xu, and R. R. Colwell. 1991. Viable but nonculturable bacteria in drinking water. Appl. Environ. Microbiol. 57:875878.

7. Chen, Y., K. M. Jackson, F. P. Chea, and D. W. Schaffner. 2001. Quantification and variability analysis of bacterial cross-contamination rates in common food service tasks. J. Food Prot. 64:72-80.

8. Fratamico, P. M., L. K. Bagi, and T. Pepe. 2000. A multiplex polymerase chain reaction assay for rapid detection and identification of
Escherichia coli $\mathrm{O} 157: \mathrm{H} 7$ in foods and bovine feces. J. Food Prot. 63:1032-1037.

9. Griffin, P. M. 1998. Epidemiology of Shiga toxin-producing Escherichia coli infections in humans in the United States, p. 15-22. In J. B. Kaper and A. D. O'Brien (ed.), Escherichia coli O157:H7 and other Shiga toxin-producing E. coli strains. ASM Press, Washington, D.C.

10. Jerse, A. E., J. Yu, B. D. Tall, and J. B. Kaper. 1990. A genetic locus of enteropathogenic Escherichia coli necessary for the production of attaching and effacing lesions on tissue culture cells. Proc. Natl. Acad. Sci. USA 87:7839-7843.

11. Luken, J. A. (Miami County Department of Health, Ohio). Personal communication.

12. Mermin, J., P. Mead, K. Gensheimer, and P. Griffin. 1996. Outbreak of E. coli $\mathrm{O} 157: \mathrm{H} 7$ infections among Boy Scouts in Maine, p. 257, K44. Abstr. 36th Intersci. Conf. Antimicrob. Agents Chemother. ASM Press, Washington, D.C.

13. Miller, A. J., T. Brown, and J. E. Call. 1996. Comparison of wooden and polyethylene cutting boards: potential for the attachment and removal of bacteria from ground beef. J. Food Prot. 59:854-858.

14. Montville, R., Y. Chen, and D. W. Schaffner. 2001. Glove barriers to bacterial cross-contamination between hands to food. J. Food Prot. 64:845-849.

15. SAS Institute. 1997. SAS/STAT software: changes and enhancements through release 6.12. SAS Institute, Inc., Cary, N.C.

16. Safranek, T. (Nebraska Health and Human Services System). Personal communication.

17. Tilden, J., Jr., W. Young, A. M. McNamara, C. Custer, B. Boesel, M. A. Lambert-Fair, J. Majkowski, D. Vugia, S. B. Werner, J. Hollingsworth, and J. G. Morris, Jr. 1996. A new route of transmission for Escherichia coli: infection from dry fermented salami. Am. J. Public Health 86:1142-1145.

18. Wachtel, M. R., and A. O. Charkowski. 2002. Cross-contamination of lettuce with Escherichia coli 0157:H7. J. Food Prot. 65:465470.

19. Wachtel, M. R., L. C. Whitehand, and R. E. Mandrell. 2002. Association of Escherichia coli $\mathrm{O} 157: \mathrm{H} 7$ with preharvest leaf lettuce upon exposure to contaminated irrigation water. J. Food Prot. 65: $18-25$.

20. Wannet, W. J., M. Reessink, H. A. Brunings, and H. M. Maas. 2001. Detection of pathogenic Yersinia enterocolitica by a rapid and sensitive duplex PCR assay. J. Clin. Microbiol. 39:4483-4486. 